\title{
Evaluation of the Activities of Antimicrobial Agents on Multi-drug Resistant Gram Positive Bacteria Isolated from Intensive Care Units
}

\author{
Sabiha Aydogdu, Murat Karamese*, Ulku Altoparlak \\ Medical Faculty, Department of Microbiology and Clinical Microbiology, Ataturk University, Erzurum 25240, Turkey
}

Received: December 8, 2013; Accepted: February 25, 2014; Published: March 03, 2014

*Corresponding author: Murat Karamese, TR 25240, Erzurum, Turkey, Tel: +90-554-863-8853; E-mail: murat_karamese@hotmail.com; murat.atauni@gmail.com

\begin{abstract}
Multi-drug resistant Gram-positive bacteria are responsible for nosocomial infections. It is important to show the minimal inhibitory concentrations and new antibiotic resistance profiles of these bacteria to antimicrobials which are commonly used in treatment. The aim was to evaluate the new and more efficient antibiotics minimal inhibitory concentrations which can be used for treatment of Gram positive multiple drug resistant microorganisms.

In this study, 337 Gram positive bacterial strains were isolated from clinical samples of 192 patients who were hospitalized at intensive care units. Minimum Inhibitory Concentration (MIC) values of antibiotics were investigated in 72 Gram positive bacterial strain Broth macrodilution and disc diffusion methods were performed to evaluate the activities of antibiotics against Gram positive bacteria.

All the 72 Gram positive bacterial strains including 38 coagulase negative Staphylococci, 18 Staphylococcus aureus and 16 Enterococci strains were sensitive to tigecycline, linezolid and daptomycin. All coagulase negative staphylococci and Staphylococcus aureus strains were sensitive to vancomycin and teicoplanin. Additionally, 2 Enterococci strains were resistant to vancomycin, while 1 strain was resistant and 1 strain was intermediately sensitive to teicoplanin.

Vancomycin, teicoplanin, tigecycline, linezolid and daptomycin might be useful and good alternative for the treatment of multi-drug resistant bacterial infections. Different antibiotic resistance profiles and the MIC's of antibiotics should be searched for the treatment of intensive care unit patients.
\end{abstract}

Keywords: Nosocomial infections; Intensive care units; Gram positive bacteria; Macrodilution

\section{Introduction}

Evaluation of the Activities of Some Antimicrobial Agents on Multi-drug Resistant Gram Positive Bacteria Isolated from Intensive Care Units.

One of the most important issues encountered in the infectious disease practice are hospital-acquired infections also referred to as 'nosocomial infections' [1]. These infections can be described as those occurring within 48 hours of hospital admission, 3 days of following discharge or 30 days after an operation. The highest rates of nosocomial infections are observed in intensive care units (ICUs), which are also the units in which the most critically ill patients are treated and the highest mortality rates are detected. The hospital-acquired infections that are seen in ICUs comprise almost $20-25 \%$ of total nosocomial infections. Antimicrobial treatment and invasive procedures, applied in ICUs, and also the immunocompromised status make patients sensitive against infections [2].

Antimicrobial agents have had crucial effects on the nosocomial infections. Approximately 25 to 35\% of hospitalized patients take systemic antibiotics [3]. However, it has become absolutely clear that the major hospital-acquired pathogens either are inherently resistant to clinically useful antimicrobial agents or possess the ability to acquire resistance. Every major class of bacterial pathogens has demonstrated an ability to develop resistance to one or more commonly used antimicrobial agents [4]. The usage of antimicrobial agents tends to create selective pressure that promotes the emergence of resistant organisms and predisposes patients to colonization with such organisms.

Gram-positive bacteria are the second most common cause of nosocomial infections with Staphylococcus aureus being the predominant pathogen. There has been an increase in the rate of antibiotic resistant bacteria associated with nosocomial infections in the ICU [5]. Bacteria develop resistance when they acquire new genetic material [6,7]. The genetic material that encodes resistance is transferred to other strains. Methicillinresistant S. aureus (MRSA) causes up to $60 \%$ of nosocomial infection in the ICU [8]. A broad-spectrum antibiotic such as Vancomycin is usually prescribed for treatment of MRSA. However, Vancomycin-resistant Enterococci and isolated cases of vancomycin-resistant $S$. aureus have been reported [9].

Therefore our objective is to evaluate MICs of the new and more efficent antibiotics which can be used for treatment of Gram positive multi-drug resistant microorganisms. 


\section{Materials and Methods}

\section{Patients and bacteria}

Evaluation of 337 Gram-positive bacterial strains isolated from clinical samples (201 blood, 72 wound, 64 sputum) of which,192 patients were hospitalized in intensive care units, organ transplantation and burn intensive care units in Ataturk University, Medical Faculty Hospital for 1 year (between June 2012 - June 2013). Isolated bacteria were stocked at $-70^{\circ} \mathrm{C}$ in $15 \%$ glycerol storage tubes with glass beads till working time. MIC values of some antibiotics were investigated in 72 Gram positive bacterial strains which were described as hospital-acquired infectious agents according to the description criteria of Centers for Disease Control and Prevention (CDC) [10].

\section{Microbial identification}

The samples obtained from the clinics were cultured onto 5\% sheep blood agar, Eosin Methylene Blue (EMB) agar and chocolate agar in incubator at $37^{\circ} \mathrm{C}$ in aerobic conditions. After 24 hours incubation, Gram staining method was performed on bacterial colonies and preparations were examined under the microscope. Catalase, coagulase and L-pyrrolidonyl arylamidase (PYR) tests were performed to identify Gram positive bacteria. After these procedures, the bacterial strains were identified by using an automated microorganism identification system (Vitek 2 compact biomerieux) to confirm the manual procedures. At the end of these tests; Staphylococcus aureus, Enterococcus spp. and coagulase-negative Staphylococci (CNS) strains were detected.

\section{Antibacterial activity assays}

The antibacterial activity was tested by using agar disc diffusion technique to determine the diameter of growth inhibition zones while broth macrodilution method was used to determine the Minimum Inhibitory Concentration (MIC).

The disc diffusion method was employed for the determination of antimicrobial activities [11]. Briefly, bacterial strains were grown overnight in Mueller-Hilton broth at an incubation temperature of $36.5^{\circ} \mathrm{C}$. The bacterial concentration was standardized to $3 \times 10^{8} \mathrm{CFU} \mathrm{\textrm {ml } ^ { - 1 }}$ using the Mc Farland scale. Antimicrobial activity was evaluated by measuring the diameters of inhibition zones. The bacterial strains and the antibiotics (Bioanalyse, Ankara, Turkey) used for disc diffusion method is shown in Table 1.

For the broth macrodilution assay [12], culture broth was placed into five $5 \mathrm{ml}$ sterile tubes using the following concentrations; 1.tube: 1:1, 2.tube: 1:2, 3.tube: 1:4, 4.tube: 1:6 and final tube: $1: 8 \mathrm{cfu} / \mathrm{ml}$ and then $1 \times 10^{6} \mathrm{CFU} / \mathrm{ml}$ of the bacterial colonies isolated from clinical samples were equally added to all tube series. The bacterial standardized inoculum (30 $\mu \mathrm{l})$ was poured into the tubes, homogenized and incubated at $36.5^{\circ} \mathrm{C}$ for 24 hours. Samples taken from the tubes were inoculated into petri dishes containing Brain-Heart Infusion Broth to verify bacterial growth. Inhibition of bacterial growth was visible as a clear broth and the presence of growth was detected by the presence of turbidity. The lowest concentration of an antimicrobial that will inhibit the visible growth of a microorganism was evaluated
Table 1: The bacterial strains and the antibiotics used for disc diffusion method.

\begin{tabular}{|c|c|}
\hline Bacterial Strains & Antibiotics \\
\hline & Cefoxitin $(5 \mu \mathrm{g})$ \\
& Erythromycin $(15 \mu \mathrm{g})$ \\
& Tetracycline $(30 \mu \mathrm{g})$ \\
& Trimethoprim-sulfamethoxazole $(25 \mu \mathrm{g})$ \\
S. aureus and CNS & Ciprofloxacin $(5 \mu \mathrm{g})$ \\
& Levofloxacin $(5 \mu \mathrm{g})$ \\
& Clindamycin $(2 \mu \mathrm{g})$ \\
& Gentamicin $(10 \mu \mathrm{g})$ \\
& Chloramphenicol $(30 \mu \mathrm{g})$ \\
\hline \multirow{3}{*}{ Enterococcus spp. } & Rifampin $(5 \mu \mathrm{g})$ \\
& Ampicillin $(10 \mu \mathrm{g})$ \\
& Levofloxacin $(5 \mu \mathrm{g})$ \\
\cline { 2 - 2 } & High-level streptomycin (300 $\mu \mathrm{g})$ \\
\hline \multirow{2}{*}{ Streptococcus spp. } & High-level gentamycin $(120 \mu \mathrm{g})$ \\
& Erythromycin $(15 \mu \mathrm{g})$ \\
& Tetracycline $(30 \mu \mathrm{g})$ \\
& Trimethoprim-sulfamethoxazole $(25 \mu \mathrm{g})$ \\
\hline
\end{tabular}

as the MIC value. MIC ${ }^{50}$ is the minimal inhibitory concentration that inhibited $50 \%$ of bacterial strains, while $\mathrm{MIC}^{90}$ is the minimal inhibitor concentration that inhibited $90 \%$ of them. The bacterial strains tested, antibiotics used and MIC testing ranges are shown in Table 2.

\section{Results}

Out of 72 Gram positive bacteria, 38 (53\%) CNS, 18 (25\%) S. aureus and 16 (22\%) Enterococcus spp were identified as hospital-acquired agents. About $70 \%$ of these pathogens were isolated from intensive care units, while the remaining isolates were obtained from the burn intensive care unit (26\%) and organ transplantation unit (4\%). Sample distribution of Gram positive bacteria isolated from ICU are shown Table 3.

According to the antibiotic susceptibility test results, 86.8\% of CNS (Staphylococcus saprophyticus and Stapylococcus epidermidis) strains were resistant to methicillin (MRCNS). The most sensitive antibiotics were rifampin, chloramphenicol, tetracycline and trimethoprim-sulfamethoxazole for MRCNS and MSCNS strains. On the other hand, $77.7 \%$ of $S$. aureus strains were resistant to methicillin (MRSA). The most sensitive antibiotics were rifampin and trimethoprim-sulfamethoxazole for MRSA and MSSA strains. All MRSA and MSSA strains were evaluated as sensitive for vancomycin, teicoplanin, tigecycline, linezolid and daptomycin by macrodilution broth method. MIC ${ }^{50}$ and MIC $^{90}$ values can be found in Table 4 for MRCNS, MSCNS, MSSA, MRSA and Enterococcus spp.

All bacterial strains (n:72) were sensitive to Tigecycline, Linezolid and Daptomycin antibiotics. However, 2 Enterococcus strains were resistant to vancomycin. The most effective antibiotic was daptomicin according to the $\mathrm{MIC}^{90}$ value. The antibiotic sensitivity rates of all bacterial strains are shown in Table 5.

\section{Discussion}

ICUs are the most important units when compared with the 
Table 2: The bacterial strains and the antibiotics used for broth macrodilution method.

\begin{tabular}{|c|c|c|c|c|c|c|}
\hline Bacterial strains & & VA & TE & TG & LZ & DP \\
\hline \multirow{3}{*}{ 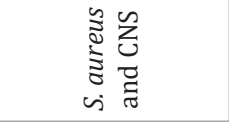 } & Testing ranges $(\mu \mathrm{g} / \mathrm{ml})$ & $0.12-4$ & $1-32$ & $0.12-4$ & $0.5-16$ & $0.12-4$ \\
\hline & \multirow{2}{*}{ Sensitivity $(\mu \mathrm{g} / \mathrm{ml})$} & $\mathrm{S}=\leq 2$ & $\mathrm{~S}=\leq 8$ & $\mathrm{~S}=\leq 0.5$ & $\mathrm{~S}=\leq 4$ & $\mathrm{~S}=\leq 1$ \\
\hline & & $\mathrm{R}=\geq 16$ & $\mathrm{R}=\geq 32$ & $\mathrm{R}=\geq 1$ & $\mathrm{R}=\geq 8$ & $\mathrm{R}=>1$ \\
\hline \multirow{3}{*}{ 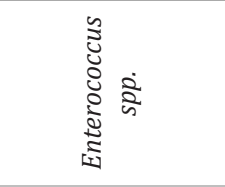 } & Testing ranges $(\mu \mathrm{g} / \mathrm{ml})$ & $2-64$ & $1-32$ & $0.12-4$ & $0.5-16$ & $2-64$ \\
\hline & \multirow[b]{2}{*}{ Sensitivity $(\mu \mathrm{g} / \mathrm{ml})$} & $\mathrm{S}=\leq 4$ & $S=\leq 8$ & $S=\leq 0.25$ & $\mathrm{~S}=\leq 2$ & $\mathrm{~S}=\leq 4$ \\
\hline & & $\mathrm{R}=\geq 32$ & $\mathrm{R}=\geq 32$ & $\mathrm{R}=\geq 0.5$ & $\mathrm{R}=\geq 8$ & $\mathrm{R}=\geq 8$ \\
\hline \multirow{3}{*}{ 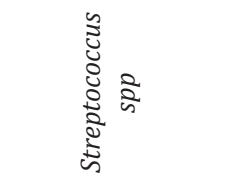 } & Testing ranges $(\mu \mathrm{g} / \mathrm{ml})$ & $0.12-4$ & $1-32$ & $0.12-4$ & $0.5-16$ & $0.12-4$ \\
\hline & \multirow[b]{2}{*}{ Sensitivity $(\mu \mathrm{g} / \mathrm{ml})$} & $\mathrm{S}=\leq 1$ & $S=\leq 8$ & $S=\leq 0.25$ & $\mathrm{~S}=\leq 2$ & $\mathrm{~S}=\leq 1$ \\
\hline & & $\mathrm{R}=\geq 32$ & $\mathrm{R}=\geq 32$ & $\mathrm{R}=\geq 32$ & $R=\geq 32$ & $\mathrm{R}=\geq 32$ \\
\hline
\end{tabular}

VA: Vancomycin, TE: Teicoplanin, TG: Tigecycline, LZ: Linezolid, DP: Daptomycin

Table 3: Clinical sample numbers of gram positive bacteria obtained from patients in the ICU.

\begin{tabular}{|c|c|c|c|c|}
\hline \multirow{2}{*}{ Clinical Materials } & \multicolumn{4}{|c|}{ Microorganisms } \\
\cline { 2 - 5 } Total \\
\hline Blood & CNS & S.aureus & Enterococcus spp & 42 \\
\hline Wound & 31 & 7 & 7 & 21 \\
\hline Cerebrospinal fluid & 3 & 11 & 0 & 2 \\
\hline Urine & 2 & 0 & 5 & 5 \\
\hline Sputum & 0 & 0 & 0 & 2 \\
\hline Total & 2 & 0 & $\mathbf{1 6}$ & $\mathbf{7 2}$ \\
\hline
\end{tabular}

Table 4: MIC ${ }^{50}$ and MIC ${ }^{90}$ values of gram positive bacteria isolated from ICUs.

\begin{tabular}{|c|c|c|c|c|c|c|c|}
\hline $\begin{array}{c}\text { Bacterial } \\
\text { Strains (72) }\end{array}$ & Antibiotics & MIC $^{50}$ & MIC $^{90}$ & $S$ & I & $\mathbf{R}$ & $\begin{array}{c}\text { MIC values } \\
(\mu \mathrm{g} / \mathrm{ml})\end{array}$ \\
\hline \multirow{5}{*}{ 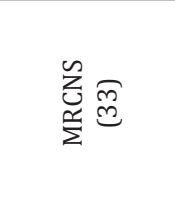 } & Vancomycin & 0.5 & 1 & 33 & 0 & 0 & $0.12-4$ \\
\hline & Teicoplanin & 1 & 2 & 33 & 0 & 0 & $1-32$ \\
\hline & Tigecycline & 0.12 & 0.25 & 33 & 0 & 0 & $0.12-4$ \\
\hline & Linezolid & 0.5 & 0.75 & 33 & 0 & 0 & $0.5-16$ \\
\hline & Daptomycin & 0.12 & 0.20 & 33 & 0 & 0 & $0.12-4$ \\
\hline \multirow{5}{*}{$\sum_{\substack{n \\
\infty}}^{\infty}$} & Vancomycin & 0.12 & 0.25 & 5 & 0 & 0 & $0.12-4$ \\
\hline & Teicoplanin & 1 & 1 & 5 & 0 & 0 & $1-32$ \\
\hline & Tigecycline & 0.12 & 0.15 & 5 & 0 & 0 & $0.12-4$ \\
\hline & Linezolid & 0.5 & 0.5 & 5 & 0 & 0 & $0.5-16$ \\
\hline & Daptomycin & 0.12 & 0.15 & 5 & 0 & 0 & $0.12-4$ \\
\hline \multirow{5}{*}{ 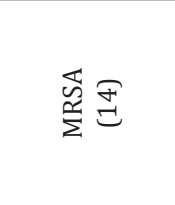 } & Vancomycin & 1 & 2 & 14 & 0 & 0 & $0.12-4$ \\
\hline & Teicoplanin & 2 & 4 & 14 & 0 & 0 & $1-32$ \\
\hline & Tigecycline & 0.25 & 0.5 & 14 & 0 & 0 & $0.12-4$ \\
\hline & Linezolid & 0.5 & 1 & 14 & 0 & 0 & $0.5-16$ \\
\hline & Daptomycin & 0.12 & 0.25 & 14 & 0 & 0 & $0.12-4$ \\
\hline \multirow{5}{*}{ 质‡ } & Vancomycin & 0.25 & 0.5 & 4 & 0 & 0 & $0.12-4$ \\
\hline & Teicoplanin & 1 & 2 & 4 & 0 & 0 & $1-32$ \\
\hline & Tigecycline & 0.12 & 0.20 & 4 & 0 & 0 & $0.12-4$ \\
\hline & Linezolid & 0.5 & 0.5 & 4 & 0 & 0 & $0.5-16$ \\
\hline & Daptomycin & 0.12 & 0.12 & 4 & 0 & 0 & $0.12-4$ \\
\hline \multirow{5}{*}{ 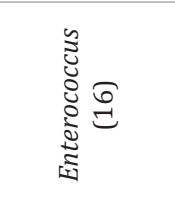 } & Vancomycin & 2 & 4 & 14 & 0 & 2 & $0.12-4$ \\
\hline & Teicoplanin & 2 & 4 & 14 & 1 & 1 & $1-32$ \\
\hline & Tigecycline & 0.25 & 0.12 & 16 & 0 & 0 & $0.12-4$ \\
\hline & Linezolid & 1 & 2 & 16 & 0 & 0 & $0.5-16$ \\
\hline & Daptomycin & 0.12 & 0.25 & 16 & 0 & 0 & $0.12-4$ \\
\hline
\end{tabular}

S: Sensitive, I: Intersensitive, R: Resistance 
other units of the hospital regarding hospital-acquired infections and resistant bacterial strains. The hospital-acquired infections detected in these units spread quickly [13]. The description of nosocomial infections in the ICU is necessary to determine the epidemiologic properties and treatment approaches. Additionally, to determine the bacterial agents and antibiotic susceptibilities is really important by the way of reducing the rates of morbidity and mortality [14]

$62 \%$ of the positive isolates were Gram negative bacteria, $47 \%$ were Gram positive bacteria and $19 \%$ were fungus respectively at one of the big clinical study named as "European Prevalence of Infection in Intensive Care (EPIC II)" that was performed in 75 countries and 1265 ICUs. These data pointed out that Gram negative bacteria generally were isolated from ICUs [15].

S. aureus and Enterococcus strains are the most isolated microorganism respectively when looking at the distribution of Gram positive bacteria isolated from ICUs. The data obtained from our study were in the same line with the current literature in the terms of isolation rates of bacterial strains. S. aureus, CNS and Enterococcus spp. were isolated from the clinical samples and most of these bacteria were isolated from blood samples of the patients who were hospitalized in ICUs $[16,17]$.

Most of the bacteria isolated from ICUs such as Acinetobacter spp., Klebsiella spp. (for Gram negative) and MRSA, MRCNS, Enterococcus spp. (for fram positive) were resistant to most antimicrobial agents especially colistin and tigecycline all over the world. The extensive use of broad-spectrum antibiotics can cause the selection of multidrug-resistant bacteria in the infections seen in ICU patients. Additionally, the general situaiton of ICU patients, the presence of underlying disease, the length of hospital stay, endogenous and resistant bacteria carriage of inpatients and application of more surgical procedures are some reasons of increasing number of resistant bacteria [18].
In the light of literature reviews, methicillin resistance is seen up to $80 \%$ in especially $S$. aureus and CNS in Turkey. It was reported that these 2 bacterial groups were resistant to methicillin at the rate of $60-100 \%$ [19]. Some Staphylococcus strains that showed intrinsic heterogenous resistance were often resistant to non-beta-lactam antibiotics (erythromycin, clindamycin, tetracycline, sulfonamides, fluoroquinolones and aminoglycosides). This situation can cause serious problems especially in staphylococcus-dependent nosocomial infections. As shown in some studies that methicillin resistant staphylococcus strains have increased resistance to most antibiotic groups such as aminoglycosides, tetracyclines, lincosamides, glycopeptides and quinolones. This situation raises the difficulty in treating multi-drug-resistant Staphylococci [20,21].

On the other hand, Enterococcus strains are reported the second most common agent after $S$. aureus for nosocomial infections. The observation of the intrinsic and acquired resistance to most of the antibiotics in Enterococci may lead to critical problems in the terms of Enterococci isolation frequency which is increasing day to day [22].

The increased number of multidrug-resistant bacterial isolation frequency in the units that specific patient groups such as ICU showed that antimicrobial agents which are durable for resistance mechanisms should be used in clinics. It has been seen that there were no resistance to any Stapylococci strains in terms of glycopeptides antibiotics, when the literature review was performed in the similar studies [23-25].

Consequently, there is an increased number of antibiotic resistance and Gram positive bacteria isolation from ICUs as nosocomial infection agents in our country and all around the world. It would be beneficial for all hospitals to search for the

Table 5: The antibiotic sensitivity rates of all bacterial strains.

\begin{tabular}{|c|c|c|c|c|c|c|}
\hline \multirow{18}{*}{ 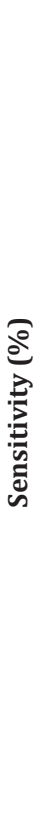 } & & & & roorgai & & \\
\hline & Antibiotics & MRCNS & MSCNS & MRSA & MSSA & Enterococcus \\
\hline & Methicillin & 0 & 100 & 0 & 100 & - \\
\hline & Tetracycline & 36.3 & 80 & 28.5 & 75 & - \\
\hline & Trimethoprim-sulfamethoxazole & 39.3 & 80 & 50 & 100 & - \\
\hline & Rifampin & 69.6 & 100 & 57.1 & 100 & - \\
\hline & High-level gentamicin & - & - & - & - & 68.7 \\
\hline & High-level streptomycin & - & - & - & - & 56.2 \\
\hline & Daptomycin & 100 & 100 & 100 & 100 & 100 \\
\hline & Tigecycline & 100 & 100 & 100 & 100 & 100 \\
\hline & Linezolid & 100 & 100 & 100 & 100 & 100 \\
\hline & Vancomycin & 100 & 100 & 100 & 100 & 87.5 \\
\hline & Teicoplanin & 100 & 100 & 100 & 100 & 93.7 \\
\hline & Levofloxacin & 42.4 & 60 & 14.2 & 75 & 31.2 \\
\hline & Clindamycin & 27.2 & 60 & 42.8 & 75 & - \\
\hline & Chloramphenicol & 72.7 & 80 & 64.2 & 100 & - \\
\hline & Gentamicin & 33.3 & 40 & 28.5 & 75 & - \\
\hline & Ampicillin & - & - & - & - & 12.5 \\
\hline
\end{tabular}


properties of agents and their known susceptibility patterns and wait for the results of microbiological culture and antibiotic susceptibility test before starting the treatment.

These multidrug resistant Gram positive bacteria particularly restrict the treatment options. Methicillin resistance strains for example MRSA and MRCNS were also showed high-resistance to other antibiotic such as teicoplanin, tigecyclin and linezolid as well as methicillin. For this reason, we must use glycopeptides on these infections however, it has to be known that this glycopeptides usage may increase vancomycin and teicoplanin resistances which have non-dangerous levels for today on Enterococci and Staphylococci. Vancomycin and teicoplanin resistance for these two bacteria should be continuously monitored. As well as glycopeptides, it is seen as a good treatment alternative to use tigecycline, daptomycin and linezolid which are sensitive against all Gram positive cocci because of their efficiency on low minimal inhibitor concentration values.

\section{References}

1. Garner JS, Jarvis WR, Emori TG, Horan TC, Hughes JM (1996) CDC definitions fornosocomial infections. In: Olmstred RN ed: APIC infection control and applied epidemiology: principles and practice, (2nd edn), St Louis, Mosby, pp. A-1-A-20.

2. Vincent JL (2003) Nosocomial infections in adult intensive care unit. Lancet 361(9374): 2068-2077.

3. Kunin CM (1981) Evaluation of antibiotic usage: a comprehensive look at alternative approaches. Rev Infect Dis 3(4): 745-753.

4. Finland M (1978) And the walls come tumbling down. More antibiotic resistance, and now the Pneumococcus. N Engl J Med 299(14): 770771

5. Witte W (1999) Antibiotic resistance in gram positive bacteria: epidemiological aspects. J of Antimicrob Chemother 44(Suppl A): 1-9.

6. Leverstein-van Hall MA, M Blok HE, T Donders AR, Paauw A, Fluit $\mathrm{AC}$, et al. (2003) Multidrug resistance among Enterobacteriaceae is strongly associated with the presence of integrons and is independent of species or isolate origin. J Infect Dis 187(2): 251-259.

7. Mooij MJ, Willemsen I, Lobbrecht M, Vandenbroucke-Grauls C, Kluytmans J, et al. (2009) Integron class 1 reservoir among highly resistant Gram-negative microorganisms recovered at a Dutch teaching hospital. Infect Control Hosp Epidemiol 30(10): 1015-1018.

8. Edgeworth JD, Yadegarfar G, Pathak S, Batra R, Cockfield JD, et al (2007) An outbreak in an intensive care unit of a strain of methicillinresistant Staphylococcus aureus sequence type 239 associated with an increased rate of vascular access device-related bacteremia. Clin Infect Dis 44(4): 493-501.

9. Azimian A, Havaei SA, Fazeli H, Naderi M, Ghazvini K, et al. (2012) Genetic characterization of a vancomycin-resistant Staphylococcus aureus isolate from the respiratory tract of a patient in a university hospital in northeastern Iran. J Clin Microbiol 50(11): 3581-3585

10. Klein Klouwenberg PM, Ong DS, Bos LD, de Beer FM, van Hooijdonk RT, et al. (2013) Interobserver agreement of Centers for Disease Control and Prevention criteria for classifying infections in critically ill patients. Crit Care Med 41(10): 2373-2378.

11. Arora S, Devi P, Arora U, Devi B (2010) Prevalence of Methicillinresistant Staphylococcus aureus (MRSA) in a tertiary care hospital in Northern India. J Lab Physicians 2(2): 78-81.

12. Siqueira ER, Ferreira JC, Pedroso RS, Lavrador MA, Candido RC (2008) Dermatophyte susceptibilities to antifungal azole agents tested in vitro by broth macro and microdilution methods. Rev Inst Med Trop Sao Paulo 50(1): 1-5.

13. Mathai AS, Oberoi A, Madhavan S, Kaur P (2012) Acinetobacter infections in a tertiary level intensive care unit in northern India: epidemiology, clinical profiles and outcomes. J Infect Public Health 5(2): 145-152.

14. Trilla A (1994) Epidemiology of nosocomial infections in adult intensive care units. Intensive Care Med 20(Suppl 3): S1-4

15. Vincent JL, Rello J, Marshall J, Silva E, Anzueto A, et al. (2009) International study of the prevalence and outcomes of infection in intensive care units. JAMA 302(21): 2323-2329.

16. Akkurt L, Gudul HS, Uyar Y, Karadag A, Esen S, et al. (2002) 1999 2000 Yllarında yogun bakım unitesinden izole edilen bakterilerde antibiyotik direnci. ANKEM Derg 16(1): 14-17.

17. Gul YS, Kurultay N, Ceken N, Yurtsever S, Afsar I, et al. (2009) Yara yeri orneklerinden izole edilen mikro organizmalar ve antibiyotik duyarlılıklarının degerlendirilmesi. ANKEM Derg 23(1): 34-38.

18. Starnes MJ, Brown CV, Morales IR, Hadjizacharia P, Salim A, et al. (2008) Evolving pathogens in the surgical intensive care unit: a 6-year experience. J Crit Care 23(4): 507-512.

19.Gulhan B, Bilek H, Onur A, Gul K (2007) Metisiline direncli stafilokoklarda linezolid, vankomisin ve bazı antibiyotiklere direnc. ANKEM Derg 21(4): 214-218.

20. Yu HH, Kim KJ, Cha JD, Kim HK, Lee YE, et al. (2005) Antimicrobial activity of berberine alone and in combination with ampicillin or oxacillin against methicillin-resistant Staphylococcus aureus. J Med Food 8(4): 454-461.

21. Srinivasan S, Sheela D Shashikala, Mathew R, Bazroy J, Kanungo R (2006) Risk factors and associated problems in the management of infections with methicillin resistant Staphylococcus aureus. Indian J Med Microbiol 24(3): 182-185.

22.(1998) National Nosocomial Infections Surveillance (NNIS) system report, data summary from October 1986-April 1998, issued June 1998. Am J Infect Control 26(5): 522-533.

23. Kurutepe S, Surucuoglu S, Gazi H, Teker A, Ozbakkaloglu B (2007) Metisiline direncli ve duyarlı Staphylococcus aureus suslarının antibiyotiklere direnc oranları. İnfeksiyon Dergisi 21(4): 187-191.

24. Waites KB, Duffy LB, Dowzicky MJ (2006) Antimicrobial susceptibility among pathogens collected from hospitalized patients in the United States and in vitro activity of tigecycline, a new glycylcycline antimicrobial. Antimicrob Agents Chemother 50(10): 3479-3484.

25. Japoni A, Farshad S, Ziyaeyan M, Ziaian S (2009) Detection of Van-positive and negative vancomycin resistant entrococci and their antibacterial susceptibility patterns to the newly introduced antibiotics. Pak J Biol Sci 12(11): 844-851. 